\title{
Maternal parity and exclusive breastfeeding history are significantly associated with stunting in children aged I 2-59 months
}

\author{
Syuhrotut Taufiqoh', Purnomo Suryantoro², Herlin Fitriana Kurniawati ${ }^{3}$ \\ 'Midwifery Master Program, Aisyiyah University, Yogyakarta, Indonesia, ${ }^{2}$ Department of Pediatrics, Faculty of \\ Medicine, Universitas Gadjah Mada Yogyakarta, Dr. Sardjito Hospital, ${ }^{3}$ Aisyiyah University, Yogyakarta
}

\begin{abstract}
ABSTRAK
Tujuan: Mengetahui hubungan paritas ibu dan riwayat pemberian ASI eksklusif dengan kejadian stunting pada anak balita usia 1259 bulan.

Bahan dan Metode: Metode observasional dengan pendekatan case control. Pengambilan sampel dengan metode purposive sampling dan jumlah sampel 118 responden. Pengumpulan data dilakukan secara observasi dan wawancara menggunakan instrumen kuesioner. Metode analisis data bivariate dengan uji chi square dan multivariate dengan regresi logistik dengan batas kemaknaan 5\% dan tingkat kepercayaan 95\%.

Hasil: Paritas ibu dan riwayat pemberian ASI eksklusif secara signifikan berhubungan dengan kejadian stunting dengan nilai masing-masing OR 3,419 (CI 95\%: 1,433-8,156) dan OR 3,706 (CI 95\%: 1,430-9,605). Variabel luar yang memiliki hubungan dengan kejadian stunting adalah pekerjaan ibu dengan nilai OR 2,972 (CI 95\%: 1,285-6,874).

Simpulan: Paritas dan riwayat pemberian ASI eksklusif secara siginifikan berhubungan dengan kejadian stunting pada anak balita usia 12-59 bulan. (MOG 2017;25:66-70)
\end{abstract}

\begin{abstract}
Objectives: To determine the relationship between maternal parity and exclusive breastfeeding history with stunting among children aged 12-59 months.

Materials and Methods: Observational method with case control approach. Sampling method used purposive sampling was conducted in 118 children. Data were collected by observation and interview using questionnaire. Chi square test used to bivariate analysis and logistic regression used to multivariate analysis with 5\% significance limit and 95\% confidence level.

Results: Multivariate analysis results that maternal parity and exclusive breastfeeding history was significantly associated with stunting (OR 3,419 (CI 95\%: 1.433-8.156); OR 3,706 (CI 95\%:1.430-9.605). External variable significantly associated with stunting is maternal occupation OR 2,972 (CI 95\%: 1.285-6.874). Conclusion: Maternal parity and exclusive breastfeeding history are significantly associated with stunting in children aged 12-59 months. (MOG 2017;25:66-70)
\end{abstract}

Key words: Parity; exclusive breastfeeding; stunting

Kata kunci: Paritas; ASI eksklusif; stunting

Correspondence: Syuhrotut Taufiqoh, Midwifery Master Program, Muhammadiyah University, Jalan Sutorejo 59 Surabaya, Indonesia. Phone: +6285707806826. E-mail: syuhrotut@gmail.com.

\section{INTRODUCTION}

Stunting is one category of nutritional problems characterized by abnormal physical growth of height based on age. Impaired growth of stunting arises due to malnutrition that occurs in a long time (chronic). Lack of intake of nutrients that are influenced by various factors become the main cause of stunting incidence in infants. ${ }^{1}$ According to data and information from Indonesia Health Profile in 2015, stunting prevalence had decreased to $29 \%$ and in year 2016 it was equal to $27.6 \%$, while the target of National Medium Term Development Plan in 2019 is $17 \%{ }^{2}$

The causes of stunting problems are complex. Its treatment requires a relatively long time because it is chronic. Chronic nutritional problems reflect the lack of protein nutrients and especially zinc that lasts a long time. One of the main causes is not providing Breast Milk (ASI) at the age of 0-24 months and lack of nutrient intake that comes from animal source. In addition, the less hygienic environment is the trigger of recurrent infectious diseases in infants and become chronic. $^{3}$

The results showed that children without exclusive breastfeeding had a 3.7 times greater risk of stunting than those given exclusive breastfeeding. Other studies mentioned that children exclusively breastfed had $51.8 \%$ growth rate better than those who were not given exclusive breastfeeding. ${ }^{4,5}$ Children born to multiparous mothers had 4.97 times more at risk of stunting compared with primiparous mothers. ${ }^{6}$

In the long term, stunting in infants will result in decreased child intelligence, behavior, and school performance. Impaired mental development is a severe impact in the future. The Public Health Center of Manukan Kulon is the highest prevalence stunting center in Surabaya, reaching 36\% (1.120 children) of 3.5912 children under five. ${ }^{7,8}$ This means nearly a third of the total number of under-fives are suffering from stunting. The purpose of this study was to determine the association of exclusive breastfeeding history and diet with 
the incidence of stunting in children aged under 12-59 months.

\section{MATERIALS AND METHODS}

This study used observational method with case control approach. Sampling was done by purposive sampling method and the sample number was 118 respondents. Independent variables in this study were maternal parity and history of exclusive breastfeeding, whereas the dependent variable was the incidence of stunting. Data were collected by observation and interview using questionnaire instrument. Data analysis method was done by univariate analysis, bivariate with chi square test, and multivariate with logistic regression with $5 \%$ significance level and $95 \%$ confidence level.

The ethics of this research used ethical clearance, informed consent, based on confidentiality, benefit and justice principles. The difficulties experienced are at the time of interview with the respondent, Respondents who came at the time of the integrated care (posyandu) operation were quite a lot, while to inquire the contents of the questionnaire on each respondent took a long time. This research used research assistant with the aim to obtain research data objectively.

\section{RESULTS AND DISCUSSION}

The number of samples researched was 118 respondents with the distribution of 59 respondents in the case group and 59 respondents in the control group. Sampling was conducted from 1,120 underfives with stunting and 2,471 underfives with normal nutritional status. Sampling was done by purposive sampling method to obtain appropriate sample with inclusion and exclusion criteria, both in case and control group. Table 1 shows the characteristics of respondents in this study.

Characteristics of the respondents by age showed that most of the respondents were toddlers aged 1 to 3 years $(58.5 \%)$, and the majority were female $(52.5 \%) .85 .6 \%$ of under-five mothers had a safe age during pregnancy, between 20-35 years. Most of the mothers had high education level and majority were as housewife (62.7\%). The majority of underfives' mothers were multiparous mothers $(66.9 \%)$. The characteristic of exclusive breastfeeding history of indicates that most underfive children were not given with exclusive breastfeeding (72\%).

Bivariate analysis of maternal parity correlation with stunting incidence showed a significant correlation with $\mathrm{p}=0.020$ OR 3.941. It can be interpreted that underfive children from multiparous mother had 4 times stunting risk compared with children from primiparous mother. Clinically, the ratio of respondents to multiparous mothers between case and control group had a difference of $28.9 \%$ proportion.

Table 1. Distribution of frequency of respondents characteristics

\begin{tabular}{|c|c|c|c|}
\hline $\mathrm{N}$ & Characteristics & $\mathrm{n}$ & $\%$ \\
\hline \multirow[t]{3}{*}{1} & Age & & \\
\hline & Toddler & 69 & 58.5 \\
\hline & Preschool & 49 & 41.5 \\
\hline \multirow[t]{3}{*}{2} & Sex & & \\
\hline & Male & 56 & 47.5 \\
\hline & Female & 62 & 52.5 \\
\hline \multirow[t]{3}{*}{3} & Age during pregnancy & & \\
\hline & At risk & 17 & 14.4 \\
\hline & Not at risk & 101 & 85.6 \\
\hline \multirow[t]{3}{*}{4} & Mother's education & & \\
\hline & Low & 24 & 20.3 \\
\hline & High & 94 & 79.7 \\
\hline \multirow[t]{3}{*}{5} & Mother's occupation & & \\
\hline & Housewive & 74 & 62.7 \\
\hline & Working & 44 & 37.3 \\
\hline \multirow[t]{3}{*}{6} & Mother's parity & & \\
\hline & Multipara & 79 & 66.9 \\
\hline & Primipara & 39 & 33.1 \\
\hline \multirow[t]{3}{*}{7} & Breastfeeding history & & \\
\hline & Not exclusive & 85 & 72 \\
\hline & Exclusive & 33 & 28 \\
\hline
\end{tabular}

Table 2. Cross-tabulation of maternal parity and a history of exclusive breastfeeding with stunting incidence

\begin{tabular}{lccccc}
\hline \multirow{2}{*}{ Variables } & \multicolumn{2}{c}{ Categories } & P & CI 95\% \\
\cline { 2 - 3 } & Case & Control & & OR & \\
\hline Parity & 48 & 31 & & 3.941 & $1.717-9.047$ \\
Multipara & 11 & 28 & & & \\
Primipara & & & 0.020 & & \\
Exclusiveness & & & 0.040 & & \\
Not exclusive & 48 & 37 & & 2.595 & $1.119-6.018$ \\
Exclusive & 11 & 22 & & & \\
\hline
\end{tabular}

Bivariate analysis of history of exclusive breastfeeding with stunting incidence showed a significant association with $\mathrm{p}=0.040$ OR 2.595 . It can be interpreted that children under five who have a history of exclusive breastfeeding are at least 3 times more likely to have stunting compared with children with a history of exclusive breastfeeding. Clinically, the ratio of respondents who did not give exclusive breastfeeding between case and control groups had a proportion difference of 
18.7\%. The maternal education association with the stunting incidence has a significant relationship based on $p$ value $=0.012$ and OR 3.878 (CI95\%: 1.413-10.646). This may indicate that mothers with low education levels have the opportunity to have children under five who experience stunting 4 times compared with mothers who are highly educated. The correlation between maternal employment and stunting incidence was significant with $\mathrm{p}=0.013$ and OR 2.836 (95\% CI: 1.3046.168 ), which means that housewives or unemployed mothers are at risk 3 times having stunting under five children compared to working mothers.
Logistic regression analysis with backward stepwise method resulted in $\mathrm{R} 2$ value in model 2 of 0.244 (24.4\%), showing that maternal parity, history of exclusive breastfeeding, and working mothers variables contributed to stunting incidence of $24.4 \%$. These results indicate that exclusive breastfeeding is the dominant variable associated with stunting incidence in underfives. Underfives with a history of not exclusively breastfed are at least 4 times more likely to have stunting compared with those with a history of exclusive breastfeeding.

Table 3. External variable cross-tabulation with stunting events

\begin{tabular}{|c|c|c|c|c|c|c|}
\hline \multirow[t]{2}{*}{ No } & \multirow[t]{2}{*}{ Variables } & \multicolumn{2}{|c|}{ Categories } & \multirow[t]{2}{*}{$\mathrm{P}$} & \multirow[t]{2}{*}{ OR } & \multirow[t]{2}{*}{ CI 95\% } \\
\hline & & Case & Control & & & \\
\hline \multirow[t]{3}{*}{1.} & Age & & & & & \\
\hline & Toddler & 36 & 33 & 0.709 & 1.233 & $0.592-2.568$ \\
\hline & Pre-school & 23 & 26 & & & \\
\hline \multirow[t]{3}{*}{2.} & Sex & & & & & \\
\hline & Males & 31 & 25 & 0.357 & 1.506 & $0.728-3.113$ \\
\hline & Females & 28 & 34 & & & \\
\hline \multirow[t]{3}{*}{3.} & Age during pregnancy & & & & & \\
\hline & Risk & 11 & 6 & 0.294 & 2.024 & $0.695-5.894$ \\
\hline & At risk & 48 & 53 & & & \\
\hline \multirow[t]{3}{*}{4.} & Mothers' education & & & & & \\
\hline & Low & 18 & 6 & 0.012 & 3.878 & $1.413-10.646$ \\
\hline & High & 41 & 53 & & & \\
\hline \multirow[t]{3}{*}{5.} & Mothers' occupation & & & & & \\
\hline & Housewives & 44 & 30 & 0.013 & 2.836 & $1.304-6.168$ \\
\hline & Working & 15 & 29 & & & \\
\hline
\end{tabular}

Table 4. Multivariate analysis between independent, dependent, and external variables

\begin{tabular}{lcc}
\hline \multicolumn{1}{c}{ Variables } & Model 1 & Model 2 \\
& OR & OR \\
& $95 \% \mathrm{CI}$ & $95 \% \mathrm{CI}$ \\
\hline Parity & & \\
Multipara & 3.220 & 3.419 \\
Primipara & $(1.341-7.736)$ & $(1.433-8.156)$ \\
Breastfeeding history & & \\
$\quad$ Not exclusive & 3.284 & 3.706 \\
Exclusive & $(1.238-8.710)$ & $(1.430-9.605)$ \\
Mothers' education & & \\
Low & 1.909 & \\
High & $(0.627-5.809)$ & \\
Mothers' occupation & & \\
Housewives & 2.537 & 2.972 \\
$\quad$ Working & $(1.057-6.090)$ & $(1.285-6.874)$ \\
$\mathrm{R}^{2}$ & 0.256 & 0.244 \\
-2 log likelihood & 138.444 & 139.785 \\
\hline
\end{tabular}


The results showed that there was a significant correlation between mothers' parity and stunting incidence in underfives. The proportion of multiparous mother was more common in case group compared with control group (28.9\%). Multiparous mothers are 3 times at risk to have stunting infants compared to primiparous mothers by involving the variables history of exclusive breastfeeding and maternal occupations. Other results suggest that children born from multiparous mothers 4.97 times more at risk of stunting compared to those from primiparous mothers. ${ }^{6}$

The history of exclusive breastfeeding with stunting incidence has a significant correlation. Stunting incidence are more likely to occur in children who are not exclusively breastfed in the first six months of life. Children who did not receive exclusive breastfeeding during the first six months of life were $30 \%$ stunting. Breast milk contains growth factors, including for the development of intestinal mucosa. Breast milk protects the baby against infection and also stimulates normal baby growth. ${ }^{9,10}$ Children who are exclusively breastfed are optimally at risk of stunting if no adequate breastmilk enhancer is added. Therefore, parents are more encouraged to meet the intake of good nutrition in children after 6 months of age and provide comprehensive breastfeeding until the age of 2 years. ${ }^{11}$

The results showed that between child's age and the incidence of stunting had a statistically significant correlation. This is in line with the results of a study which states that the age is not a factor associated with the incidence of stunting in children aged 0-59 months $(p=0.31)$. The results showed that the majority of children with stunting were $25-59$ months old. ${ }^{12}$ This is not in line with the results of a study in Bangladesh that shows that the child's age significantly influences the incidence of stunting. The age of children with stunting is predominantly $12-23$ months $(16.1 \%) .{ }^{6.13}$

The rate of growth of children in the first year of life is faster than at any other age. When viewed from the age of toddlers, the incidence of stunting is widely found at the age of 12 to 59 months. The increase in body length is faster in the first year than in subsequent years. Toddler growth rate is higher than the preschool age. The average increase in height in the first year is $26 \mathrm{~cm}$, second year $11 \mathrm{~cm}$, third year $10 \mathrm{~cm}$, fourth year $7 \mathrm{~cm}$, and fifth year $8 \mathrm{~cm} .{ }^{14,15}$

The results of statistical analysis showed that between children's sex and the incidence of stunting had no significant correlation. Another study suggests that boys and girls have equal opportunities to experience stunting. ${ }^{16}$ It is not in line with the results of the study that boys have a chance of 4.01 (CI95\%: 2.32-6.95\%) to experience stunting compared to girls. ${ }^{12}$ Other results suggest that boys aged 0-59 months are at risk of stunting compared with girls. ${ }^{17}$

Maternal age during pregnancy and the incidence of stunting had no significant correlation $(\mathrm{p}=0.294)$, but there is a tendency that pregnant mothers at risk of age have twice the chance of having stunting children compared with pregnant women at a safe age. The results are consistent with other studies that maternal age that is too young or less than 20 years has 1.54 times greater risk of stunting. Another study mentioned that the incidence of stunting was more common in infants born to mothers aged 35-44 years. ${ }^{18,19}$

The result of analysis showed that there was no significant correlation between maternal education level and stunting incidence in under fives. The results of this study are not in line with some previous research results which state that maternal education can affect the ability in health care, including the provision of nutrition in children. The results of other studies have shown that underfives from parents with elementary education have a higher risk of stunting incidence compared to underfives of higher-educated parents. ${ }^{20}$ Parental education is an important element that can affect the nutritional state of the family because higher education levels can help in establishing a good concept between diet and health. ${ }^{21}$

The result of statistical analysis showed that mother's occupation and stunting incidence in children under five have significant correlation. Housewives have a chance to have a stunting child 3 times higher compared with working mothers. Other results suggest that housewives and working mothers have the same opportunity to have children with stunting ( $\mathrm{p}=0.304$ and OR 2.37) (CI95\%: $0.46-12.21){ }^{12}$ The results of this study are not in line with the results of studies found that working mothers tend to have little time to care for children. Other results indicate that, rather than than housewives, mothers who work as farmers and traders have a higher risk of stunting children. ${ }^{22}$

\section{CONCLUSION}

History of exclusive breastfeeding, maternal parity, and maternal occupation are some of the factors significantly associated with stunting in underfives children. Government as the policy maker has socialized the importance of early stunting prevention. Participation of health workers, parents and families of the children as a direct party in an effort to improve the quality of child health is needed. 


\section{ACKNOWLEDGMENT}

We express our gratitude to all respondents in this study as well as the health center and the Surabaya City Health Office that has facilitated and granted permission in data collection for this study.

\section{REFERENCES}

1. Terati S, Sartono, Nazarena, Yunita. Studi determinan kejadian stunting pada anak balita pengunjung posyandu wilayah kerja Dinas Kesehatan Kota Palembang. Tesis. Yogyakarta: Universitas Gadjah Mada; 2013.

2. Ministry of Health. Data dan informasi profil kesehatan. Jakarta: Kementerian Kesehatan; 2017.

3. Surabaya Municipal Health Office. Laporan Kegiatan Tahunan. Surabaya: Dinas Kesehatan Pemerintah Kota Surabaya; 2016.

4. Dewi DP. Status Stunting. Kaitannya dengan pemberian ASI Eksklusif pada Balita di Kabupaten Gunung Kidul. Jurnal Medika. 2015;10(4).

5. Masyhudi K. Hubungan pemberian ASI eksklusif, pengetahuan, pendapatan dan pola asuh dengan tumbuh kembang anak balita di desa Meudheun Kecamatan Jaya, Aceh Utara. Jurnal Serambi Saintia. 2016;5(2).

6. Kizilyildiz B, Sonmez B, Karaman K, et al. Prevalence, demographic characteristik and associ-ated risk factors of malnutrition among 0-5 aged children: A cross sectional study from Van, Eastern Turkey. Pediatric Journal. 2016;8:6112.

7. UNICEF Indonesia. Kemitraan antara Pemerintah Indonesia, UNICEF, dan Uni Eropa dalam membantu mengatasi tantangan gizi untuk anak. Pusat Media. 2012.

8. Habaasa G. An investigation on factors associated with malnutrition among underfive children in Nakaseke and Nakasongola Districts, Uganda. BMC Pediatric Journal. 2015:5;134.

9. Chirande L, Charwe D, Mbwana H, et al. Determinants of stunting and severe stunting among underfive in Tanzania: Evidence from the 2010 cross sectional household survey. BMC Pediatrics Journal. 2015;15:165.

10. Proverawati A and Ismawati C. Berat Badan Lahir Rendah (BBLR). Yogyakarta: Nuha Medika; 2010.

11. Black RE, Allen LH, Bhuta ZA, et al. Maternal and child undernutrition: Global and regional exposures and health consequences. The Lancet Jornal, 2008; 371: 243-260.

12. Cruz LMG, Azpeitia GG, Suarez DR, et al. (2017). Factors associated with stunting among children age 0-59 months from the central region of Mozambique. Nutrient Journal. 2017;9:491.

13. Alemu Z, Ahmed A, Yalew A, Birhanu B, Zaitchik, B. Individual and community level factors with significant role in determining child height for age $\mathrm{z}$ sore in East Gojjam Zone, Amhara Regional State, Ethiopia: a Multilevel analysis. BMC Archives of Public Health Journal. 2017;75:27.

14. Fitri. Berat lahir sebagai faktor dominan terjadinya stunting pada balita $12-59$ bulan di Sumatera (Analisis Data Riskesdas 2010). Tesis. Jakarta: Universitas Indonesia. 2012.

15. WHO. WHO child growth standards methods and development. Media Center. 2017.

16. Derso T, Tariku A, Andargiebiks G, Wassie MM. stunting, wasting and associated factors among children aged 6-24 months in Dabat Health and Demographic Surveillance System site: A community based cross sectional study in Ethiopia. BMC Pediatrics Journal. 2017;17:96.

17. Chirande L, Charwe D, Mbwana $\mathrm{H}$ et al. Determinants of stunting and severe stunting among underfive in Tanzania: Evidence from the 2010 cross sectional household survey. BMC Pediatrics Journal. 2015;15:165.

18. Semali IA, Kessy AT, Mbaga EJ, Leyna G. Prevalence and determinants of stunting in under five children in Central Tanzania. Remaining thre-ats to achieving Millenium Development Goal 4. BMC Public Health Journal. 2015;15:1153.

19. Darteh EK, Acquah E, Kumi KA. Correlated of stunting among children in Ghana. BMC Public Health Journal. 2014;14(1):504.

20. Ikeda N, Irieb Y, Shibuya. Determinant Of reduced child stunting in Cambodia: Analysis of pooled data from three demographic and health surveys. Bull World Health Organization Journal. 2013:91;34149.

21. Michael GJ, Lanhan SA, Cassidy A. Gizi kesehatan masyarakat. Wiley. (Andry Hartono, Pen.). Jakarta: EGC; 2009.

22. Fikadu T, Assegid S, Dube, L. Factors associated with stunting among children of age 24 to $59 \mathrm{im}$ Monthin Meskan District, Gurage Zone, South Ethiopia: A case control study. BMC Public Health Journal. 2014;14:800. 